\title{
Green Growth, Food Safety and Environnement Quality: Theoretical Study in Developing Countrys
}

\author{
Sawssen NAFTI \\ Faculty of Economics and Management of Sousse Laboratory, University of Sousse Street of Khalifa El \\ KarouiSahloul - BP n० 526 - 4002 Sousse Tunisia \\ correspondingauthor: sawssen_nafti@yahoo.fr \\ ORCID identifier: 0000-0002-4022-7467
}

\begin{abstract}
This paper examines the relationship between green growth, food safety and environnement protection. Our analysis is based on a theoretical study aimed to know if the green economy is an effective solution to the problem of poverty and under-nourishment and protective of the environment in developing countrys or it is just a component of any strategy for growth economy. In this way, green economic theories encompass a wide range of ideas all dealing with the interconnected relationship between people and the environment. Our theorical study shows that green economy have an important role to reducing environmental risks and ecological scarcities, also is a good solution to reduce poverty, under-nourishment and assure food safety, if political orders is made.
\end{abstract}

Keywords: Green economy- food safety, environmental protection, economic growth JEL Classification : Q48- Q18- F1-O4

\section{1- Introduction}

The green economy covers all economic activities linked directly or indirectly to the protection of the environment, the management of scarce resources, renewable energies, climate change and risk prevention. The notion of green economy is one of the many closely related concepts which have emerged in recent years and which aim to strengthen the convergence between the three pillars of sustainable development. In its Green Economy Report, the United Nations Environment Program (UNEP) defines it as an economy aimed at improving human well-being and reducing inequalities in the long run, while preserving generations. future environmental risks and major ecological shortages.

More simply, the green economy can be defined as a low-carbon, resource-efficient economy that facilitates social integration and protects, while strengthening, biodiversity and ecosystem services. The green economy is above all about, on the one hand, developing an economic system that strengthens and enhances the Earth's natural capital and, on the other hand, maximizing economic benefits and minimizing social inequalities. Ultimately, it is a results-oriented concept that aims to improve human well-being without compromising the resources on which current and future generations depend for their livelihoods. It serves to link economic performance with a rational use of resources and an equitable distribution of benefits within and between generations. So The transition to a green economy presents both challenges and opportunities. However, is the concept of green economy appropriate for all economies and all levels of development?

This study is organized as follow: Firstly, we show a review of previous literature on the nexus between green growth ,food safety, poverty and environnement protection. Secondly, we explore the notion of green economy in the context of development, Thirdly, we give the different solotions giving by economic growth to protect environnement and reduce poverty and assure food safety and finally we give a concluding remarks.

\section{2-Literature review}

The majority of economists have attached great importance to agriculture and its direct influence on economic growth. For Lewis (1954), agriculture is the basis of capital formation, frees labor deemed to be poorly 
productive in order to supply other sectors, particularly industry by forming a market for industrial products that supply foreign currency, in turn financing imports. Gillis (1990) considers that agriculture, through its profit potential, serves to attract foreign direct investment which in turn creates jobs and opens up new investment niches for the benefit of local entrepreneurs allowing an increase in local production. According to the World Bank (2008), Agriculture contributes to development since it was an economic activity, livelihood and provider of environmental services, making it a unique development instrument.

This is confirmed by a study carried out by Patrick Guillaumont in 2003, based on the work of Barro and Sala-iMartin (1996), which concludes that only environmental conditions (through the agricultural sector) have a significant and very important impact. on production growth

In this sense, like any economic sector, the agricultural sector needs financing to make a better contribution to growth. In fact, financial resources condition to a very important part the accessibility to the inputs and the equipment necessary for the adoption of an intensive production system. However, the literature reveals a lack of financing in agriculture in many developing countries.

FAO (1996) notes underinvestment in agriculture over the past decade in many developing countries. She finds that a large part of public spending on agriculture is allocated to subsidies, so little public resources are left for the creation of new infrastructure or for other growth-generating spending. According to FAO experts (1996), due to insufficient funding, many government agricultural support services function poorly, rural roads are impassable for much of the year, agricultural machinery is unusable and irrigation schemes are in poor condition, as erosion, deforestation and salinization continue to accelerate, at an ever-increasing rate. It is also noted that, since the mid-1980s, official development assistance for agriculture has declined significantly (FAO, 1996).

In the literature, education is the factor most cited by authors as an explanatory factor for the level of efficiency of producers (Zonon, 2003). However, there is no overall consensus regarding the impact of investment in education on the productivity of farmers. Gurgand $(1994,1997)$ finds that education has zero or even negative returns in agriculture in Ivory Coast. On the other hand, Tilak (1993) and Coltear (1990) review several studies in Asia and Europe showing that education significantly increases productivity.

\section{3-The green economy in the context of development}

Sustainable development will remain beyond our reach if we do not find solutions that allow us to live with what the planet has to offer; it will also remain so if there is no hope for a better life for all on this unique planet. A new approach to economic growth is therefore necessary. Ways must be found to integrate environmental sustainability with economic growth and well-being by disconnecting growth from overexploitation of the environment as well as social injustices and inequalities. 'Environmental sustainability', 'sustainable consumption and production', 'green growth', 'climate resilience', 'low emission strategies',' inclusive growth 'and' decent jobs Can serve as a means to reconcile the demands of economic growth with the growing scarcity of natural resources and the challenges of poverty. This will require, as we know, a profound transformation of the socioeconomic system. The global financial and economic crisis of 2008/2009 provided an unprecedented opportunity to bring about the necessary transformations, thus giving more force to all these concepts.

The idea of a new ecological deal was then launched by many institutions (New Green Deal 2008). Starting with a package of economic recovery measures, the Green New Deal emphasizes how to get the world back on track by freeing it from a combination of economic, environmental and social crises. The call has been heard by many governments. This is how the administration

In this sense, the transition to a green economy presents both challenges and opportunities. However, is the concept of green economy appropriate for all economies and all levels of development?

\section{3-1-For developed countries}

For developed countries, a green economy supported by green growth requires radical changes in behavior and a shift in public opinion. It also requires strong and clear signals from public authorities, but also from individuals - citizens and consumers - that they are ready to make environmental and social sustainability a priority. The hardest part about this is changing behavior and transforming institutions to enable the adoption of sustainable 
production and consumption patterns. Public policy reform at all levels - local, regional, national and international - is needed to make private and civic action more attractive

\section{3-2-For developing countries}

The principles of the green economy can also be applied successfully in developing countries, including Africa, and lead to economic growth that benefits all segments of society and is environmentally sustainable in the medium and long term. Given its level of development, Africa must adopt a very different development path from that of other regions: this is a strategic advantage that it must exploit. It can skip the stage of dirty and inefficient technologies and products and therefore avoid the most polluting and less sustainable production and consumption processes. The technologies implemented should draw on indigenous and local knowledge and use a combination of low-tech solutions (cleaner stoves that use fuel more efficiently, for example), medium-tech solutions (green infrastructure, for example) and high-tech such as solar technology. Conversely, Africa must avoid locking itself into situations where polluting technologies are used because they are less costly in the short term.

Developing countries are those where consumption can grow the most as a large part of the population still lacks access to the most basic products and meeting basic needs will lead to increased consumption and from production. Therefore, advocating for development using polluting and resource-intensive technologies and unsustainable approaches would further undermine sustainability and long-term poverty reduction.

Whether long-established or emerging, economic and social orders will have to be transformed in order to become "sustainable", without however excluding improving social protection and ensuring an acceptable level of development for all. Ensuring a high level of human development for all - enabling everyone to realize their potential and lead productive and creative lives that meet their aspirations and needs - is clearly essential.

The green economy can provide many opportunities to mobilize resources for a low-carbon development path that resists climate change. However, there will be enormous obstacles to overcome for green economies to contribute to the goals of sustainable development and poverty reduction as well as to improving social protection and the quality of life of the people of Africa. Indeed, these developments will inevitably lead to an increase in consumption, especially of food, energy and water. In this regard, the role of policies and investments intended to sustain and increase the natural heritage (soils, forests, fishery resources), heritage on which the survival of many poor communities depends, could be decisive. At the same time, the economic system will have to develop, in order to improve the terms of trade of African countries, by increasing its productive activities. For a short period of time, the path to the green economy could prove onerous, possibly running counter to institutional priorities, which demand the resolution of more urgent and pressing development challenges, and reduction targets. short-term poverty.

\section{4-Obstacles to overcome and openings to exploit}

\section{4-1- In the short term}

The green economy can provide many opportunities to mobilize resources for a low-carbon development path that resists climate change. However, there will be enormous obstacles to overcome for green economies to contribute to the goals of sustainable development and poverty reduction as well as to improving social protection and the quality of life of the people of Africa. Indeed, these developments will inevitably lead to an increase in consumption, especially of food, energy and water. In this regard, the role of policies and investments intended to sustain and increase the natural heritage (soils, forests, fishery resources), heritage on which the survival of many poor communities depends, could be decisive. At the same time, the economic system will have to develop, in order to improve the terms of trade of African countries, by increasing its productive activities. For a short period of time, the path to the green economy could prove onerous, possibly running counter to institutional priorities, which demand the resolution of more urgent and pressing development challenges, and reduction targets. short-term poverty. 


\section{4-2- In the long term}

However, in the long term, the green economy will lead to sustainable and poverty-reducing economic growth: it will be necessary to lead the transition in such a way as to safeguard the most needy social categories and to involve it in policies aimed at strengthening equity and poverty reduction. In the short term, the actions launched should focus on exploiting existing openings, at zero or very low costs, as well as conversion possibilities. The choice of a green economy can and must be a development strategy for the benefit of all, avoiding taking up the paradigm of "growth first, cleaning then", which has proved to be unsustainable and, ultimately, even more costly. when external factors (including health impacts and irreversible damage) are taken into account. Investment strategies should differentiate between large sectors, for example those which are large consumers of resources, investments or energy, especially infrastructure. Government subsidies harmful to the environment should be regulated or limited. On the other hand, health, education and cultural activities and services are among the sectors requiring increased investment. It is also important to create decent jobs and promote lowresource and energy-efficient investments.

Thus, sustainable consumption and production must be key elements of the green economy in Africa, an economy that favors more efficient, better informed and less resource-intensive consumption patterns, providing opportunities for the creation of jobs and leads to equitable growth and development, thus making it possible to meet basic needs and improve the living conditions of growing populations of Africa. At the same time, the consumption and production of one country can have negative impacts in other countries (notably through the discharge of waste and pollution from second-hand and used electronic products), it is necessary to put in place policies to ensure that cross-border trade does not undermine continental efforts for sustainable development.

No sector is as important as agriculture for economic and social well-being. This represents $34 \%$ of the GDP of sub-Saharan African countries and employs around $70 \%$ of the population of these countries. A green economy for sustainable development and poverty eradication will face some of the challenges facing this sector. For example, climate change and ecosystem degradation will have a negative impact on agriculture, including lower productivity of rain-fed agriculture. In the African context, the green economy must adopt the principles of green agriculture and sustainable irrigation practices in order to preserve soil quality, increase biodiversity and ensure higher levels of productivity to feed an expanding population.

\section{5-Governance, means of action and mechanisms promoting conversion}

No sector is as important as agriculture for economic and social well-being. This represents 34\% of the GDP of sub-Saharan African countries and employs around $70 \%$ of the population of these countries. A green economy for sustainable development and poverty eradication will face some of the challenges facing this sector. For example, climate change and ecosystem degradation will have a negative impact on agriculture, including lower productivity of rain-fed agriculture. In the African context, the green economy must adopt the principles of green agriculture and sustainable irrigation practices in order to preserve soil quality, increase biodiversity and ensure higher levels of productivity to feed an expanding population.

Structural transformation of the agricultural sector is necessary to increase productivity and added value, and it must be accompanied by economic diversification policies that highlight intersectoral linkages and dependency relationships as part of an integrated approach. However, all the implications of this structural transformation must be taken into account, for example the potential negative effects of the concession of large agricultural areas to foreign companies, environmental and social impacts, etc.

The development and adoption of appropriate and sustainable technologies should be encouraged (e.g. efficient irrigation techniques, mechanization, improved livelihoods, better methods of measuring productivity taking into account inputs and externalities, for example). Important ancillary benefits can be obtained (agro biodiversity, reduction of water pollution through better use of inputs, for example), and these must be highlighted in order to promote the sustainable transformation of the environment. Agriculture.

With regard to agriculture and land use, for example, the following policy instruments can be used: improving market access for sustainable products; trade policies; reduction of tariff and non-tariff barriers; improvement of production and processing standards; promotion of eco-labels to encourage the development of new products; 
establishment of a system of positive and negative incentives to encourage production that takes more account of social and environmental concerns (in particular the elimination of harmful subsidies).

Most of the aforementioned instruments as well as various other useful measures to make African agriculture greener have already been integrated into the Comprehensive Africa Agriculture Development Program (CAADP), which is a framework put in place under the leadership of the AUC-NEPAD to transform African agriculture. This framework, to which the African heads of state and government have subscribed, is organized according to four major priority themes (also called pillars):

a) Increase the areas subject to sustainable soil and water management.

b) Improve market access through better rural infrastructure and market interventions.

c) Increase food supply and reduce hunger.

And d) Improve research and agricultural systems to disseminate appropriate new technologies.

To date, 24 countries have used the CAADP framework to reorient their agricultural strategies and have signed multi-stakeholder engagement documents called CAADP compacts.

\section{6-Conclusion}

The green economy is an very important concept on several levels of governance. This was firstly examined by Pearce et al. (1989) and continued through the 'Green New Deals' and progress at Rio+20. In this way, green economy is widely used in national policy frameworks in different in countries. In this paper, we examined the relationship between green economy, food safety and environnement protection. Our analysis is based on a theoretical study aimed to know if the green economy is an effective solution to the problem of poverty and under-nourishment and protective of the environment or it is just a component of any strategy for growth economy.We conclued that, green economy is an economy that aims to reducing environmental risks and ecological scarcities, and that aims for sustainable development without degrading of the environment, also is good solution to reduce poverty, under-nourishment and assure food safety, if political orders is made.

\section{References}

[1] Ahmed W, Ashraf MS? Khan SA, Kusi-Sarpong S, Arhin FK, Kusi-Sarpong H, Najmi A (2020), Analyzing the impact of environmental collaboration among supply chain stakeholders on firm's sustainable performance.In: Operations Management Research,pp1-18.

[2] BOURG Dominique, KAUFMANN Alain et MÉDA Dominique (dir.) (2016), L’Âge de la transition. En route pour la reconversion écologique, Paris, Les Petits matins, Institut Veblen.

[3] Banque Mondiale (2007), World Development Indicators 2007, Washington.

[4] Blanc, A. (2021). Un modèle de comportement rationnel vis-à-vis de la pollution intérieure. Revue française d'économie, 3(3), 177197. https://doi.org/

[5] CILSS (2003), Foncier rural et développement durable au Sahel et en Afrique de l'Ouest, Document de synthèse régionale, Bamako, $48 \mathrm{p}$.

[6] CIRAD et al (2002), Le financement de l'agriculture familiale dans le contexte de libéralisation : quelle contribution de la microfinance? Résumé exécutif du séminaire de DAKAR

[7] Destek MA, Sarkodie SA (2019) Investigation of environmental Kuznets curve for ecological footprint: the role of energy and financial development. Sci Total Environ 650:2483-2489

[8] Du K, Li J(2019) Towards a green world:how do green technology innovations affect total-factor carbon productivity.Energy Policy 131:240-250.

[9] Elfahli.K \& Hossari. H(2021).Green human resource management: A systematic literature review.International Journal of Accounting, Finance, Auditing, Management and Economics,2(2). 236-266.https://doi.org/10.5281/zenodo.4641478.

[10] FAO (1996), Investissement dans le secteur agricole: évolution et perspectives, Document d'information technique, Rome. 
[11] Fethi S, Rahuma A (2019) The role of eco-innovation on CO 2 emission reduction in an extended version of the environmental Kuznets curve: evidence from the top 20 refined oil exporting countries. Environ Sci Pollut Res 26(29):30145-30153

[12] Gillis Malcolm et al. (1990), Economie du développement, De Boeck-Wesmael, s. a.Bruxelles, 734p

[13] Grellet Gérard (1986), Structures et stratégies du développement économique, PUF, Paris, 471p.

[14] Institut National de la Statistique et de la Démographie (2008), Statistiques structurelles disponible sur http://www.insd

[15] Julio Henao et Carlos Baanante (1999), L'épuisement des éléments nutritifs dans les terres agricoles de l'Afrique, IFPRI, disponible sur www.ifpri.org/french/2020/Briefs/BR62FR.HTM

[16] Mundlak Yair et al. (2002), Determinants of Agricultural Growth in Indonesia, the Philippines, and Thailand, World Bank Development Research Group, Washington, 82p.

[17] Mathieu Catherine, «Brexit : quel impact macroéconomique selon la littérature ? », Annales des Mines - Réalités industrielles, 2021/1 (Février 2021), p. 9-13. DOI : 10.3917/rindu1.211.0009. URL : https://www.cairn.info/revue-realites-industrielles-2021-1-page-9.htm

[18] Merlin-Brogniart, C. (2021). Les services comme levier « écologique » de l'industrie : proposition d'un cadre d'analyse.

[19] Sanchez P. et Sachs J. (2004), Une révolution verte pour l'Afrique, in le Monde du 10 aout 2004

[20] Rapport de la New Economics Foundation: A Neen 2008,http:/www.neweconomics.org/sites/neweconomics.org/files/A_Green_New_Deal_1.pdf

[21] Raza SA, Shah N, Sharif A (2019) Time frequency relationship between energy consumption, economic growth and environmental degradation in the United States: Evidence from transportation sector. Energy 173:706-720

[22] Blog « Business as usual is not an option » : http://oecdinsights.org/2010/10/15/business-as-usual-isnot-an-option/

[23] Études de cas de l'Institut international du développement durable (IISD) sur le paiement des services éco systémiques : http://www.watershedmarkets.org/regions/centralamerica_caribbean.html

[24] Rapport du Fonds mondial pour la nature (WWF): Planète vivante 2010: Biodiversité, Bio capacité et développement http://www.wwf.fr/s-informer/actualites/rapport-planete-vivante-2010-comment-va-laplanete

[25] Travaux de l'OCDE sur la croissance verte: www.oecd.org/greengrowth

[26] Tsayem Demaze, Moïse, et Angéline Chartier (2021). "Comment la géographie est-elle impliquée dans la construction des connaissances sur la transition énergétique ? Un état de l'art et des pistes d'approfondissement des recherches [1] », Annales de géographie, vol. 737, no. 1, , pp. 5-34.

[27] Töbelmann D, Wendler T (2020) The impact of environmental innovation on carbon dioxide emissions. J Clean Prod 244:118787

[28] Princeton University : Pacala and Socolow Stabilisation Wedges, http://cmi.princeton.edu/wedges/

[29] Initiative du PNUE en matière d'économie verte: http://www.unep.org/greeneconomy/

[30] World Bank, \& OECD, (2019). World development indicators, GDP per capita (US\$). http://data.worldbank.org/indicator/NY.GDP.PCAP.CD.

[31] Isa, N.M., Sivapathy, A. and Adjrina Kamarruddin, N.N. (2021), "Malaysia on the Way to Sustainable Development: Circular Economy and Green Technologies", Sergi, B.S. and Jaaffar, A.R. (Ed.) Modeling Economic Growth in Contemporary Malaysia (Entrepreneurship and Global 